\title{
Referendums in the UK Constitution: Authority, Sovereignty and Democracy after Brexit
}

\author{
Michael Gordon*
}

\begin{abstract}
UK constitution after Brexit - Status of referendums - Use and reception of referendums in the UK - Absence of definitive constitutional framework - Complex legal nature of 'advisory' and 'binding' referendums - Deeper constitutional impact on concepts in the political constitution - Regular and irregular authority Parliamentary and popular sovereignty - Representative and direct democracy Possibility of reform - A potential UK Referendums Act - Difficulties with an overarching statutory framework - Limitations of continued constitutional accommodation of referendums
\end{abstract}

The 2016 referendum on membership of the European Union has been a defining moment in the UK's constitutional politics. Since the vote to 'leave', almost every dimension of that referendum has been evaluated and re-evaluated in public debate: the timing of the vote, the franchise, the question, the lack of a supermajority threshold, the absence of consensus across the UK's four nations, the conduct of the official and unofficial campaigners, the spending in those campaigns, the factors defining voter choices, and how to interpret and implement the decision. The Brexit referendum defeated two Prime Ministers (so far): David Cameron for failing to win for 'remain', Theresa May for failing to persuade Parliament to accept the Withdrawal Agreement negotiated with the EU. There were three extensions to the original two-year Article 50 negotiating process, which were contested to the point where they consumed UK politics, and two general elections were required to produce an outcome to conclude the exit process. During the period that the UK's exit was being negotiated, there were intense

*Professor of Constitutional Law, University of Liverpool. I'm grateful to the editor and reviewers for helpful comments on the initial text of this paper.

European Constitutional Law Review, 16: 213-248, 2020

(C) The Author(s), 2020. Published by Cambridge University Press on behalf of European Constitutional Law Review. This is an Open Access article, distributed under the terms of the Creative Commons Attribution licence (http://creativecommons.org/licenses/by/4.0/), which permits unrestricted re-use, distribution, and reproduction in any medium, provided the original work is properly cited. doi:10.1017/S1574019620000152 
debates about the need for a further referendum to resolve the uncertainty, while others argued for a more abrupt end to the process, whether in the form of exit without a deal, or unilateral revocation of the initial notice of withdrawal. The UK's legal and political system has been totally dominated by attempts to understand, accommodate, and respond to this referendum decision for over four years.

There was a time when referendums were a peripheral part of the UK constitution. The UK was a representative democracy with a sovereign Parliament - it was not necessary for the people to be directly engaged in political decisionmaking. Referendums were for reformists, ${ }^{1}$ obstructionists, ${ }^{2}$ or Europeans. ${ }^{3}$ Members of Parliament were chosen (and peers in the House of Lords were born) to exercise their good judgement on our behalf. Governments might respond to public opinion, but would not be led by it. We had moved some way past this position at the time of the 2016 referendum, and the need to consider direct democratic processes when making decisions of high constitutional significance was becoming established. ${ }^{4}$ Yet while referendums had arguably become a normal part of the constitutional architecture by the early years of the $21^{\text {st }}$ century, there was a lack of consistency and an abundance of complacency concerning their use. This inconsistency was demonstrated by the difficulty in identifying clear criteria which defined when a referendum would (or would not) be held. And this complacency was fuelled by the fact that the results produced by referendums were previously anticipated by the political class, and did not require the government and legislature to embark on a course of action to which they had been opposed. This was a constitutional accommodation, rather than a constitutional embrace, of referendums.

Brexit has seen the relatively benign position of referendums dramatically unravel. Against that backdrop, this paper re-evaluates the constitutional status of referendums in the UK. Having outlined the use and reception of referendums in the UK, surveying existing practice and influential reports from the House of Lords Constitution Committee and Independent Commission on Referendums, it makes three key arguments. First, the paper explores the legal status of referendums in the UK constitutional system, based around a distinction between direct democratic decisions which have 'advisory' or 'binding' effects. In identifying this

${ }^{1}$ See J. Meadowcroft and M.W. Taylor, 'Liberalism and the Referendum in British Political Thought 1890-1914', 1 Twentieth Century British History (1990) p. 35.

${ }^{2}$ See V. Bogdanor, The People and the Party System (Pitman Press 1981) p. 33, on discussions by anti-suffragists of the potential utility of referendums to their cause.

${ }^{3}$ See A.V. Dicey, Introduction to the Study of the Law of the Constitution, $8^{\text {th }}$ edn (Macmillan 1915) p. 372, Note VIII on 'Swiss Federalism'. See also the famous comments of the Labour leader Clement Atlee in 1945: 'I could not consent to the introduction into our national life of a device so alien to all our traditions as the referendum'.

${ }^{4}$ See S. Tierney, Constitutional Referendums: A Theory and Practice of Republican Deliberation (Oxford University Press 2012). 
distinction, we can see the multifaceted nature and position of UK referendums but also, as the paper argues, it demonstrates the inadequacy of a purely legal analysis of these instruments, especially given the 'political' character of the UK constitution. ${ }^{5}$ Consequently, from the political constitutionalist perspective, it becomes important to consider the deeper constitutional impact of the incorporation of referendums into the UK's decision-making machinery.

Second, the paper examines how the UK's constitutional concepts are potentially being reshaped by our experience of referendums, focusing specifically on the core ideas of authority, sovereignty, and democracy. The paper discusses the tensions which referendums reveal between regular and irregular sources of authority, parliamentary and popular sovereignty, and representative and direct democracy - and experience of the 2016 Brexit referendum and its aftermath exhibits these issues starkly. Yet it argues that considerations of authority, sovereignty and democracy also show the role of referendums in providing a different impetus in a changing constitution, rather than exposing them as mechanisms which cannot fit with some pristine, pre-existing UK system. As a result, the paper argues that it is important to understand how referendums operate in a wider constitutional framework, which is not based on stark choices between absolutes, but is open to recalibration to achieve different ends.

Third, the paper considers the future of referendums in the UK's decisionmaking architecture. In particular, it explores how the constitutional framework in which referendums sit might be (re)structured. The paper argues that a new Referendums Act may provide a clearer and more consistent way of integrating referendums into the UK's constitutional framework. The widespread and continuing failure to seriously consider this possibility may be understandable in practice, but it serves to emphasise and potentially exacerbate the legal and conceptual tensions arising from the UK's experience of referendums. The paper therefore suggests that we should consider how to bring greater coherence to the constitutional framework in which referendums will continue to be influential, both to better organise their future use, and to better reflect their contemporary significance in the structures of the UK constitution.

\section{The USE AND RECEPTION OF REFERENDUMS IN THE UK}

The UK's relationship with referendums is quite particular and, from a comparative perspective, peculiar. While 'the general practice in Europe is for a national referendum to be provided for in the constitution', ${ }^{6}$ the absence of a codified text

\footnotetext{
5.A.G. Griffith, 'The Political Constitution', $42 \operatorname{MLR}(1979)$ p. 1.

${ }^{6}$ Venice Commission, Referendums in Europe (2005) at [19], 〈www.venice.coe.int/webforms/ documents/default.aspx?pdffile=CDL-AD(2005)034-e〉, visited 14 July 2020.
} 
makes this impossible in the UK. Yet equally, direct democracy is arguably always idiosyncratic, ${ }^{7}$ given the national variations possible between referendums which are mandatory, initiated by governmental authorities, or initiated by citizens. ${ }^{8}$ In many ways, the UK's constitutional debate on referendums is narrower than many European debates, since it has primarily focused on ad hoc, 'tactical', 'top-down' referendums. ${ }^{9}$ Yet the UK approach is also presented in (potentially) more dramatic terms, with the people viewed not as another 'organ of state', ${ }^{10}$ or technical partner in decision-making, but a superior political entity which sits beyond the institutions of government, above even the sovereign Parliament. ${ }^{11}$ Nonetheless, while there are important differences between the experience of the UK and (for example) the Irish requirement of a referendum in the constitutional amendment process, ${ }^{12}$ or the elaborate Swiss system of popular initiatives, ${ }^{13}$ the UK's relative constitutional openness means the broader dilemmas posed by direct democracy resonate here too. The 2018 repeal of the short-lived Advisory Referendum Act in the Netherlands clearly illustrates the kind of challenge faced by the UK: how the constitutional system should adapt in recognition of the growing significance of direct democratic decision-making. ${ }^{14}$

There have been a range of referendums, on a number of topics, at different levels of the UK, dating back to the 1970s. There have been three national referendums held across all of the UK: in 1975 on continued membership of the European Union, in 2011 on whether to adopt the Alternative Vote system for elections to the House of Commons, and in 2016 (again) on whether to leave or remain a member of the EU. There have also been eight referendums held exclusively in particular constituent nations of the UK: a border poll on the status of Northern Ireland in $1973,{ }^{15}$ two referendums on whether to adopt devolved governments in Scotland and Wales in $1979,{ }^{16}$ two referendums (again) on

\footnotetext{
${ }^{7}$ A. Auer in Venice Commission, Constitutional Justice and Democracy by Referendum (1995) p. 139, 〈www.venice.coe.int/webforms/documents/default.aspx?pdffile=CDL-STD(1995)014-e , visited 14 July 2020.

${ }^{8}$ See M. Setala and T. Schiller (eds), Referendums and Representative Democracy (Routledge 2009) chs. 1 and 11.

${ }^{9}$ A. Auer, 'The People Have Spoken: Abide? A Critical View of the EU's Dramatic Referendum (In)experience', 12 EuConst (2016) p. 397 at p. 400.

${ }^{10}$ Ibid., p. 401.

${ }^{11} \mathrm{I}$ 'm grateful to the editor for this point.

${ }^{12}$ Constitution of Ireland, Arts. 46-47.

${ }^{13}$ Federal Constitution of the Swiss Confederation, Arts. 138, 139, 140, 141.

${ }^{14}$ See M. Qvortrup, The Conversation (6 March 2018), 〈https://theconversation.com/why-thedutch-plan-to-scrap-advisory-referendums-is-a-step-back-for-democracy-92705 $\rangle$, visited 14 July 2020.

${ }^{15}$ Northern Ireland (Border Poll) Act 1972.

${ }^{16}$ Scotland Act 1978; Wales Act 1978.
} 
whether to adopt devolved governments in Scotland and Wales in $1997,{ }^{17}$ a referendum on the Good Friday peace agreement in Northern Ireland (and also separately in the Republic of Ireland) in $1998,{ }^{18}$ a referendum on whether to expand devolved government in Wales in $2011,{ }^{19}$ and a referendum on Scottish independence in $2014 .{ }^{20}$ There have also been a number of regional referendums in parts of England and Wales concerned with establishing new layers of local government. The two most high profile were in London on the creation of a directly elected Mayor and Greater London Assembly in 1998, ${ }^{21}$ and in the North East of England on whether to establish an elected Regional Assembly in 2004. ${ }^{22}$ There have also been some 59 local referendums in parts of England or Wales on whether to establish (or remove) the position of directly-elected mayor within a local authority, ${ }^{23}$ two local referendums on whether to change to a committee system of local government, ${ }^{24}$ and one referendum on whether to increase council tax by an amount above the allowed $3 \%$ threshold. $^{25}$

The patterns here are relatively clear, with referendums being held on four broad topics: (i) membership of the UK; (ii) membership of the EU; (iii) devolution of powers to new institutions of government within the UK; (iv) change to the voting system. These are major constitutional questions, cutting to the centre of the democratic state and its identity. Yet while it may be easy to discern patterns from those referendums which have been held, there is still inconsistency. This is apparent when considering situations in which referendums have not been held. For example, a referendum was not held to approve the Lisbon Treaty, a significant

\footnotetext{
${ }^{17}$ Referendums (Scotland and Wales) Act 1997.

${ }^{18}$ Northern Ireland (Entry to Negotiations, etc) Act 1996; Northern Ireland Negotiations (Referendum) Order 1998.

${ }^{19}$ Government of Wales Act 2006.

${ }^{20}$ Scottish Independence Referendum Act 2013.

${ }^{21}$ Greater London Authority (Referendum) Act 1998.

${ }^{22}$ Regional Assemblies (Preparations) Act 2003.

${ }^{23}$ See M. Sandford, 'Directly-elected Mayors', House of Commons Library Briefing Paper (No. 05000, 7 May 2019) Appendix 3. These referendums were introduced under the Local Government Act 2000. Among many referendums of this kind held since 2000, in May 2012 the Conservative-Liberal Democrat Coalition Government required ten referendums to be held in the largest cities in England. In only one city (Bristol) was the vote in favour of creating a directly-elected mayor; nine others rejected the proposal. Two further City Councils (Liverpool and Leicester) agreed to adopt the mayoral model without a referendum.

${ }^{24}$ Ibid.

${ }^{25}$ See M. Sandford, 'Council Tax: Local Referendums', House of Commons Library Briefing Paper (No. 05682, 1 November 2019). Provisions also exist for local referendums to be held in the planning context, for the adoption of Neighbourhood Development Orders or Plans; see The Neighbourhood Planning (Referendums) Regulations 2012. For discussion, see J. Sturzaker and M. Gordon, 'Democratic Tensions in Decentralized Planning - Rhetoric, Legislation and Reality in England', 35 Environment and Planning C: Politics and Space (2017) p. 1324.
} 
reform to the legal architecture of the EU, despite pressure on (then) Prime Minister Gordon Brown, ${ }^{26}$ and the promises of David Cameron when (then) Leader of the Opposition. ${ }^{27} \mathrm{~A}$ referendum was not held to approve either major expansion of Scottish devolution in 2012 or $2016 .{ }^{28}$ New Labour's initial reform of the House of Lords was not subject to approval at a referendum and, despite serious disagreement among the leaders of the main political parties about whether further Lords reform should be pursued without a national vote in 2012, this was not part of the proposals developed (but then ultimately abandoned) at this time. ${ }^{29}$ And at the regional level, while many referendums have been held on the adoption of directly-elected mayors within local authorities, the more high-profile (UK government-led) creation of 'Metro Mayors' with enhanced powers and resources covering wider geographical 'Combined Authorities' have not been subject to ratification at referendums. ${ }^{30}$

The lack of a clear prescriptive test which determines when referendums should be held is very apparent. While patterns have emerged, there is no real sense that they are either consistently followed or coherent in their coverage. This is arguably a consequence of the ad hoc, circumstantial decision-making surrounding referendums. The enactment of the Political Parties, Elections and Referendums Act 2000 provides (among other things) a regulatory framework which (unless set aside or supplemented by specific enabling legislation) governs how a referendum must be conducted. But there is an absence of a specific constitutional framework establishing the circumstances in which referendums can or should be held. Where can we turn, then, to obtain guidance regarding the position of referendums within the UK's constitutional system?

The 2010 report 'Referendums in the United Kingdom' by the House of Lords Select Committee on the Constitution has been a particularly influential attempt

\footnotetext{
${ }^{26}$ 'Brown assailed by accusations of betrayal over EU treaty deal', The Independent (23 October 2007), (www.independent.co.uk/news/uk/politics/brown-assailed-by-accusations-of-betrayal-overeu-treaty-deal-397614.html $\rangle$, visited 14 July 2020.

${ }^{27}$ 'David Cameron admits Lisbon treaty referendum campaign is over', The Guardian (4 November 2009), 〈www.theguardian.com/politics/2009/nov/04/david-cameron-referendum-campaign-over , visited 14 July 2020.

${ }^{28}$ Scotland Act 2012; Scotland Act 2016.

${ }^{29}$ 'Coalition decides against referendum on House of Lords reform', The Guardian (23 June 2012): 〈www.theguardian.com/politics/2012/jun/23/coalition-referendum-houselords-reform $\rangle$.

${ }^{30}$ Cities and Local Government Devolution Act 2016. Indicative referendums were held to assess public support for a North East devolution deal in Durham in 2016, and a Yorkshire-wide devolution deal in Barnsley and Doncaster in 2017. But neither deal has (yet) come to fruition, and the referendums were not held across the entire areas which would have become part of the proposed Combined Authorities. See M. Sanford, 'Devolution to Local Government in England', House of Commons Library Briefing Paper (No. 07029, 15 May 2019).
} 
to understand the role of referendums in the UK. We can compare this pre-Brexit parliamentary report with the more recent post-Brexit referendum report of the Independent Commission on Referendums, published in July 2018. This Commission was established by the Constitution Unit at University College London, and its 12 members included past and present senior civil servants, politicians, journalists, academics and other members of civil society. In different ways, and while reflective of their publication at very different times, these reports offer a clear picture of the dominant approach to the constitutional position of referendums.

The House of Lords Constitution Committee report concluded that there were 'significant drawbacks to the use of referendums'. ${ }^{31}$ In particular, the Committee noted 'we regret the ad hoc manner in which referendums have been used, often as a tactical device, by the government of the day'. ${ }^{32}$ Despite this scepticism about their utility, the Committee accepted that 'if referendums are to be used, they are most appropriately used in relation to fundamental constitutional issues. ${ }^{33}$ The Lords did not, however, commit to a definition of what this would encompass: ' $[\mathrm{w}] \mathrm{e}$ do not believe it is possible to provide a precise definition of what constitutes a "fundamental constitutional issue". ${ }^{34}$ Nevertheless, the Constitution Committee did offer a non-exhaustive list of seven examples which would fall within this category: 'to abolish the Monarchy', 'to leave the European Union', 'for any of the nations of the EU to secede from the Union', 'to abolish either House of Parliament', 'to change the electoral system for the House of Commons', 'to adopt a written constitution', 'to change the UK's system of currency'. ${ }^{35}$ Given the Committee's indicative rather than definitive approach to identifying when referendums should be used, it is little surprise that the report concluded that this process could not be further formalised in statute: 'it is impossible to set out in legislation an all-encompassing list of such issues that should be subject to a referendum'. ${ }^{36}$ The Constitution Committee did nonetheless reaffirm that it was for Parliament not the government to decide whether a referendum was required (somewhat inevitably, given the need for authorising legislation for each referendum), and recommended that the test should be 'whether an issue raises "an important question of principle about a principal part of the constitution"'. ${ }^{37}$ In terms of the imposition of conditions on the results of referendum decisions,

\footnotetext{
${ }^{31}$ House of Lords Select Committee on the Constitution, Referendums in the United Kingdom (HL Paper 99, 12 ${ }^{\text {th }}$ Report of Session 2009-10, published 17 March 2010), [62].

${ }^{32}$ Ibid., [62].

${ }^{33}$ Ibid., [94].

${ }^{34}$ Ibid., [94].

${ }^{35}$ Ibid., [94].

${ }^{36}$ Ibid., [111].

${ }^{37}$ Ibid., [118].
} 
the report recommended 'that there should be a general presumption against the use of voter turnout thresholds and supermajorities' ${ }^{38}$

The Constitution Committee's focus was therefore on the basic principles which should inform the use of referendums. The report is underpinned by scepticism, both about the general utility of the referendum as a decision-making mechanism, and the extent to which it ought to be more formally incorporated into the UK's constitutional framework. It is possible that the former is connected to the latter, with the Committee's doubts about the value of referendums influencing its conclusions that they could not and should not be firmly integrated into the architecture of the UK political system. The reluctance of one parliamentary committee (no matter how influential as a constitutional actor, given its elite membership) to provide clear prescription in relation to such a challenging topic is certainly understandable. There may be virtue in leaving it open to political actors to develop a principled constitutional practice associated with referendums absent a comprehensive framework, subject to guiding principles about the centrality of Parliament and the norm of simple majoritarianism. Yet this also clashes with one of the Committee's key concerns: the overtly political use of the referendum as a tactical device, which very open definitions framed by reference to broad ideas of constitutional significance or principle do little to inhibit.

Two key things stand out about the Constitution Committee's report. First, the overwhelming emphasis on constitutional issues - however defined - as being the potential trigger for a referendum to be held. On this approach, the social, political, or economic significance of an issue is clearly secondary to whether it touches on the essential constitutional framework of the UK's legal and political system. Second, the non-exhaustive list of issues on which referendums would need to be held seems to map well onto the UK's practice both before and after the report was published in 2010. Referendums on electoral reform, Scottish independence, and leaving the EU have all been held, and while it seems difficult to imagine the abolition of monarchy, the pound, or adoption of a written constitution in the immediate future, it would be even more difficult to argue that those events lack the requisite significance to be decided by the electorate directly. The abolition of either House of Parliament may be more controversial as a general norm, especially in its application to the House of Lords, which has been significantly reformed without approval at a referendum, and debates concerning further reform remain live. ${ }^{39}$ Yet equally, much may turn on whether 'abolition' is understood to include 'replacement' of the Lords with an elected chamber, and it

\footnotetext{
${ }^{38}$ Ibid., [189].

${ }^{39}$ 'Rebecca Long-Bailey wants to abolish the House of Lords', The Guardian (20 January 2020), 〈www.theguardian.com/politics/2020/jan/12/rebecca-long-bailey-wants-to-abolish-the-house-of-lordsscottish-independence), visited 14 July 2020.
} 
is probably unsurprising that the Constitution Committee would be in favour of trying to establish additional hurdles which might slow down far-reaching change to the House of Parliament in which it sits.

We can compare the approach of the Lords Constitution Committee with the report of the Constitution Unit's Independent Commission on Referendums. Between 2010 and 2018, the ground had shifted significantly. Therefore, while the Constitution Committee could argue (perhaps slightly conservatively) at the start of 2010 that ' $r$ r] eferendums may become a part of the UK's political and constitutional practice', at the end of that decade this claim seems more than fulfilled. As such, in the 2018 report of the Independent Commission there is a greater focus on effective regulation of referendums, to address problems revealed by experience. The proposals include amendment of the Political Parties, Elections and Referendums Act 2000 to update the legal framework according to which referendums are held, changes to the role of government and designated lead campaigners during referendums, increasing transparency around campaign spending, and enhanced regulation of online political advertising in particular. ${ }^{40}$

But while this is a detailed and substantial report, based on a wide range of comparative evidence, in common with the Constitution Committee's report there is some underlying scepticism towards referendums and their incorporation within the UK's constitutional system. The Commission finds that the use of referendums in the UK is 'driven by political pragmatism, not constitutional principle. ${ }^{41}$ Referendums 'legitimise and provide a degree of entrenchment for key decisions' which, mirroring the earlier approach of the Constitution Committee, are defined as 'appropriate' in relation to 'major constitutional change. ${ }^{42}$ While accepting that referendums 'have an important role to play in the democratic system', ${ }^{43}$ the Independent Commission report also reflects unease about their overall impact: ' $[\mathrm{i}] \mathrm{n}$ thinking about the role of referendums we should therefore consider how these can best coexist with our system of representative democracy, and be mindful of the risks of undermining it. ${ }^{44}$ The Commission therefore concludes that ' $\mathrm{u}$ ] ntil effective ways of ensuring the democratic quality of referendums have been found, they should be used with caution'. ${ }^{45}$

The Independent Commission's report is therefore some way from a ringing endorsement of the potential of direct democracy. In focusing on better regulation to mitigate the risks which direct democracy might pose, there is also little new in the Commission's approach to the broader constitutional framework in which

\footnotetext{
${ }^{40}$ Report of the Independent Commission on Referendums (Constitution Unit, UCL July 2018).

${ }^{41}$ Ibid., 46.

${ }^{42}$ Ibid., 46 .

${ }^{43}$ Ibid., 9.

${ }^{44}$ Ibid., 68.

${ }^{45}$ Ibid., 68.
} 
referendums sit. On the question of whether there should be formalised prescription of the circumstances in which referendums ought to be held, the view of the Lords Constitution Committee is repeated: 'the Commission does not consider it appropriate to attempt to legislate for all the topics on which referendums should be required'. ${ }^{46}$ The reasoning is also familiar, based on definitional difficulties: '[a]lthough there is broad consensus that referendums should be held on "constitutional issues", there is a lack of cross-party agreement on what should be considered a "constitutional issue" and whether all "constitutional issues" are appropriate to be put to referendum, ${ }^{47}$

So like the House of Lords Constitution Committee's report before it, the Independent Commission report is effectively endorsing the status quo as regards the constitutional status of referendums. The Independent Commission's report is detailed and persuasive on the need for further regulation in a number of ways, but avoids bigger questions about how referendums should be positioned in the UK's political system. The dominant approach is therefore one which emphasises the constitutional character of the decisions suitable to be taken at referendums, without engaging with the challenge of how they might be better integrated into the wider constitutional framework. The issue may be too big to expect resolution from any one Committee or Commission, but an approach which leans on relatively empty ideas like 'major' or 'fundamental' constitutional change is problematic as a basis for explaining when referendums might appropriately be held. Such a definition purports to draw the boundaries quite narrowly, while at the same time offering limited guidance about when direct democratic decisions might be considered. It exploits the vagaries of the terminology of the 'constitutional', rather than exploring the specific means by which the referendum might be incorporated into the constitution itself. Yet unless we try to respond to this challenge, it is an invitation for inconsistency and complacency to persist.

Could this hesitancy or scepticism about the integration of referendums into the UK's constitution be suggestive of a deeper concern? It might be thought that any attempt to formally incorporate referendums into the political architecture would suffer from a fatal flaw: the (apparent) poor fit of referendums in the UK's constitutional paradigm. For example, the Independent Commission concluded that: 'In the absence of a codified constitution it would not be possible definitively to limit the circumstances in which referendums are held or to require a supermajority before a referendum can be called. Parliament would remain free to repeal any restrictions by simple majority or hold ad hoc referendums enabled by new primary legislation'. ${ }^{48}$ This might suggest that, in the UK, the constitutional

\footnotetext{
${ }^{46}$ Ibid., 77.

${ }^{47}$ Ibid., 77.

${ }^{48}$ Ibid., 76.
} 
position of a referendum decision is inherently precarious because of parliamentary sovereignty. Even if the circumstances in which referendums should be held were more precisely defined in primary law, Parliament could legislate to displace or ignore any statutory criteria at the very moment it decided to hold a referendum or avoid a previous requirement. The insecure legal status of referendums could, therefore, prevent any change to their constitutional position. However, as the next section will discuss, the legal status of referendums is more complicated than superficial reference to the fundamental constitutional norm of parliamentary sovereignty might suggest.

\section{THE LEgAL STATUS OF REFERENDUMS IN THE UK}

The precarious legal status of referendums flows from the fact that the UK constitution is based on the doctrine of parliamentary sovereignty. Every referendum held in the UK must be based on legal authority. The legal basis for a referendum to be held has always been provided in primary legislation, which serves as the highest form of constitutional law in the UK. This is a consequence of the doctrine of parliamentary sovereignty: Parliament has a legally unlimited legislative power, and can decide to make or unmake any law at any moment. This legislative sovereignty includes a legally unfettered power to call a referendum on any matter. At the same time, however, parliamentary sovereignty can be viewed as a barrier preventing any standing rules being enacted which would definitively fix the circumstances in which referendums were required. So while parliamentary sovereignty provides the legal authority for a referendum to be held (on any matter, at any time), it is also a constraint on the adoption of a legal framework which mandates when referendums must occur. In the face of a future exercise of sovereign legislative authority, those rules could be displaced.

Therefore, the constitutional fundamental of parliamentary sovereignty appears superficially to be inconsistent with the idea of authoritative legal decisionmaking through referendums. Yet there is an even deeper sense in which legislative sovereignty poses problems for the authority of a referendum. The very decision taken at a referendum itself can also be seen to lack binding legal force. If the representative legislature which is allocated sovereignty is constitutionally superior to any other body, even a decision taken directly by the electorate must remain legally susceptible to being ignored or overturned by Parliament. An expression of the will of the electorate at a referendum has effect only within a broader constitutional scheme of parliamentary authority. Popular sovereignty can, therefore, be viewed as inevitably subject to parliamentary sovereignty. However, in practice and in principle, the constitutional position of a referendum is more complex than is suggested by focusing only on the sovereign legislative 
authority of the UK Parliament. When considering the legal status of a decision taken in a referendum, we need to consider both the authority of the device as a matter of legal principle, and any consequences specified as a matter of positive law.

To explore the legal status of referendums in the UK, we can initially distinguish between 'advisory' and 'binding' referendums. While useful to structure the discussion and demonstrate the variation in the models of referendums we find in the UK's constitutional system, we will see that even this framing device is too simplistic.

\section{Advisory referendums}

The standard assumption is that the doctrine of parliamentary sovereignty makes a referendum decision legally 'advisory'. Parliament legislates to ask the people directly for their view on a specific issue, but the expression of that view merely amounts to providing advice to the legally sovereign decision-maker, which may proceed in any way it wishes.

This approach was evident in the classic work of Dicey on parliamentary sovereignty. For Dicey, the sovereignty of Parliament was continuing, which meant any individual Parliament was unable to 'bind its successors. ${ }^{49} \mathrm{~A}$ legal requirement to comply with the result of a referendum would be a clear example of an impermissible limit binding future Parliaments. Yet Dicey's position did not remain static. Dicey came to defend referendums as one of a number of vehicles (of considerably varying legitimacy) for resisting Home Rule in Ireland..$^{50}$ On this approach, the referendum gave the people a veto on major political change which Parliament sought to implement. ${ }^{51}$ While some believe that this evolution in Dicey's thought represented a shift of faith from parliamentary to popular sovereignty, ${ }^{52}$ it seems better to understand this as an instrumental conversion which also led him to publicly defend armed resistance as a means of preventing the creation of a Parliament in Ireland. ${ }^{53}$ At the least, Dicey's change of heart concerning the acceptability of referendums indicates that there has never been a time when their position in the UK constitution was a straightforward matter. But, as in many ways, the detail of Dicey's actual views have come to assume less importance than

\footnotetext{
${ }^{49}$ Dicey, supra n. 3, p. 65.

${ }^{50}$ See A.V. Dicey, A Leap in the Dark; or Our New Constitution (John Murray 1893) p. 197-201.

${ }^{51}$ See M. Qvortrup, 'AV Dicey: The Referendum as the People's Veto', 20(3) History of Political Thought (1999) p. 531.

${ }^{52}$ See R. Weill, 'Dicey was not Diceyan', 62 CLJ (2003) p. 474.

${ }^{53}$ See A.V. Dicey, A Fool's Paradise: Being a Constitutionalist's Criticism on the Home Rule Bill of 1912 (John Murray 1913). For commentary, see H. Tulloch, 'AV Dicey and the Irish Question: 1870-1922', 15 Irish Jurist (1980) p. 137; Lord Bingham, 'Dicey Revisited', PL [2002] p. 39.
} 
the attitudes widely associated with his constitutional writing. In that sense, the influence of the Diceyan approach to parliamentary sovereignty, defended by scholars like William Wade, ${ }^{54}$ has been in establishing the limited legal status of referendums. $^{55}$

Many of the major referendums held in the UK appear to fit this 'advisory' model. The devolution referendums in 1997 and 1998, and the referendums on EU membership in 1975 and 2016 were all 'advisory' in nature, in the sense that they relied on Parliament to implement decisions which were recommended by the electorate. The referendum decisions themselves had no direct legal consequences. Either further legislation would be required to bring about the changes sought by a majority of voters, or no action was required, in which case the status quo would automatically be preserved. In relation to devolution, the referendums were implemented through the subsequent enactment of separate legislation establishing new institutions and structures of governance for Scotland, ${ }^{56}$ for Wales, ${ }^{57}$ and for Northern Ireland. ${ }^{58}$ In relation to the EU, the 1975 referendum required no action to sustain the continuing membership of the UK. Then following the referendum in 2016, a legislative trilogy was necessary to begin the exit negotiations, ${ }^{59}$ to prepare the domestic legal system for the withdrawal of EU norms, ${ }^{60}$ and to conclude the final Withdrawal Agreement. ${ }^{61}$

This position is reflected in the view of the courts. The major constitutional case of Miller, ${ }^{62}$ which concerned the involvement of Parliament in the process of commencing the formal Brexit negotiations, was a direct consequence of the decision taken to leave the EU in the 2016 referendum. In its analysis of the significance of this decision-making process, a majority of eight (of a panel of eleven) Supreme Court Justices noted that ' $[\mathrm{t}]$ he referendum is a relatively new feature of UK constitutional practice'. ${ }^{63}$ A referendum decision had no automatic legal effect: 'The effect of any particular referendum must depend on the terms of the statute which authorises it... the authorising statute may enact a change in the law subject to the proviso that it is not to come into effect unless approved

${ }^{54}$ H.W.R. Wade, 'The Basis of Legal Sovereignty', 13 CLJ (1955) p. 172.

${ }^{55}$ See A.L. Young, 'Populism and Parliamentary Sovereignty: the Goldsworthy Solution', in L. Burton Crawford et al. (eds), Law Under a Democratic Constitution: Essays in Honour of Jeffrey Goldsworthy (Hart Publishing 2019) p. 178-179.

${ }^{56}$ Scotland Act 1998.

${ }^{57}$ Government of Wales Act 1998.

${ }^{58}$ Northern Ireland Act 1998.

${ }^{59}$ European Union (Notification of Withdrawal) Act 2017.

${ }^{60}$ European Union (Withdrawal) Act 2018.

${ }^{61}$ European Union (Withdrawal Agreement) Act 2019.

${ }^{62} R$ (Miller) v Secretary of State for Exiting the European Union [2017] UKSC 5.

${ }^{63}$ Ibid., [117]. 
by a majority in the referendum'. ${ }^{64}$ In this case, the 2016 referendum 'did not change the law in a way which would allow ministers to withdraw the United Kingdom from the European Union without legislation... It means that, unless and until acted on by Parliament, its force is political rather than legal'. ${ }^{65}$ As a result, the fact that the decision to exit the EU had been taken at a referendum was seen as irrelevant to the Supreme Court's decision, which was ultimately a question of the extent of the government's prerogative power. ${ }^{66}$ The existence (or as the Supreme Court decided, the absence) of a prerogative power to commence Brexit negotiations - an international act by the government which could (eventually) have had an impact on domestic law - was not changed or validated by the fact that this would have been executive action to implement a direct decision of the electorate. Instead, new legislation by Parliament was required to trigger negotiations with the EU.

As the Supreme Court observed in Miller, it is possible for legislation authorising a referendum to prescribe automatic legal consequences in advance of the decision. While this was not done in the European Union Referendum Act 2015, which established the legal authority for the Brexit referendum, it has been done in other instances. For example, in the Parliamentary Voting System and Constituencies Act 2011, statutory changes to electoral law were prescribed in advance of the referendum, in the same legislation authorising the public vote. A Minister was placed under a legal duty to bring these changes into effect by a statutory instrument if the decision at the referendum was in favour of using a new Alternative Vote system for elections to the House of Commons. ${ }^{67}$ Similar provisions were used in the legislation underpinning the first devolution referendums in Scotland and Wales in the late 1970s, albeit requiring more than a simple majority of those voting in the referendums to authorise a Minister to make an order bringing these new systems of governance into effect. ${ }^{68}$

Yet even where legal consequences automatically flow from a decision, as set out in the authorising statute, as a matter of constitutional principle these decisions are still technically 'advisory'. For while a Minister may be placed under a statutory duty to make an order bringing about specified legal changes, the sovereignty of Parliament means that the legislature would still possess the lawful authority to reverse or repeal these duties if it did not want the referendum result implemented. This reality can be recognised in the arrangements made for the

${ }^{64}$ Ibid., [118].

${ }^{65}$ Ibid., [124].

${ }^{66}$ See also Lord Reed (dissenting on the main point) at [171].

${ }^{67}$ Parliamentary Voting System and Constituencies Act 2011, ss. 8-9.

${ }^{68}$ Scotland Act 1978, s. 85; Wales Act 1978, s. 80 . The failure to secure the necessary level of popular support in each of these referendums placed Ministers under an alternative statutory duty: to make an order repealing the primary legislation. 
prescribed implementation of referendum results: the 1978 Acts discussed above provided that a draft commencement order must be laid before and approved by resolution of both Houses of Parliament before it could have legal effect. Further, given the legally unlimited law-making power of Parliament extends to authorise retrospective legislation, ${ }^{69}$ it is difficult to imagine any statutory mechanism for automatic implementation of a referendum result which could not be overturned using legislative sovereignty. There would, of course, be significant political costs to reversing a referendum decision in this way. As the Supreme Court noted in the Cherry/Miller case considering the legality of Prime Minister Boris Johnson's fiveweek prorogation of Parliament, in relation to the 2016 EU referendum: 'Technically, the result was not legally binding. But the Government had pledged to honour the result and it has since been treated as politically and democratically binding. Successive Governments and Parliament have acted on that basis'.$^{70}$ Any move to avoid implementing a referendum result, especially where the consequences had been set out in advance in an authorising statute, would only increase the sense that political and democratic constraints had been disregarded.

Adopting a wider constitutional perspective, we must therefore question the 'advisory' status of referendums. Referendums are complex decision-making mechanisms due to their democratic character as a direct expression of the will of the (voting) people. Their constitutional position is more than simply a reflection of their formal legal status: decisions taken at a referendum have an overriding moral-political authority in a democratic state. If a constitutional system is to be founded on democracy, referendums acquire a constitutional authority by virtue of this normative underpinning of the system - they represent an expression of the popular will which is essentially irresistible. This is not due to their legal force, although of course part of the legitimacy of a referendum stems from its basis in law, and the need for it to be held in accordance with the law. Instead, decisions taken at a referendum cannot merely be disregarded, because of their structural and normative grounding in the rules and values of the political constitution. This arguably gives an even greater weight to the outcome of a referendum, extending beyond that which can be formally attributed to a decision-making process by legal norms. The entrenched authority of the devolution settlement, for example, is in significant part a product of the fact that this democratic scheme was approved directly by the peoples of Scotland, Wales and Northern Ireland

${ }^{69}$ See War Damage Act 1965 , s. 1.

${ }^{70} R$ (Miller) v The Prime Minister; Cherry v Advocate General for Scotland [2019] UKSC 41, [7]. The same point was made in other litigation concerning Brexit; see the Court of Appeal in $R$ (Wilson) v The Prime Minister [2019] EWCA Civ 304, [9]: 'Although the EU referendum was only advisory, the Conservative Party Manifesto had said that the result would be honoured; and, following the referendum result, the Government announced its intention to give notice of withdrawal from the EU'. 
respectively - the legitimacy and endurance of the UK's devolved system of government is underpinned by the popular approval derived from these referendums.

The 'advisory' status of a referendum decision therefore has a number of aspects, depending on whether it is considered from a purely legal or wider (political) constitutional perspective. Yet even the legal status of referendums is more complex than might be expected given the enduring centrality of the sovereignty of Parliament. For there are ways of understanding sovereignty which allow a degree of binding legal force to attach to a procedural requirement like the need for a referendum to be held. There are also a growing number of practical examples of the UK Parliament enacting legislation which appears to make compliance with the outcome of a referendum a necessary part of the legal process for making certain decisions.

\section{Binding referendums}

The extent to which referendums can become a binding part of the legislative process has been the subject of much academic debate. The traditional Diceyan position that a sovereign Parliament cannot bind its successors would prohibit any alteration of the legislative process, whether to incorporate a referendum requirement or any other additional procedural step. ${ }^{71}$ This general position was challenged by Jennings and Heuston. These 'manner and form' theorists argued that one Parliament could require a future Parliament to follow an alternative law-making process - or a new 'manner and form' for the lawful enactment of legislation. ${ }^{72}$ This would be a legitimate exercise of Parliament's legally unconstrained sovereign authority as long as it was: (i) a procedural change to the future legislative process, rather than an absolute substantive limit on the power of its successors; and (ii) established in an Act of Parliament which was enacted in accordance with the law-making process for the creation of valid statute law in operation at the time. For those defending a 'manner and form' approach to parliamentary sovereignty, this was not about one Parliament 'binding' or constraining its successors, but rather about establishing that the law-making process itself was not ossified, or immunised from legitimate alteration by the sovereign (and democratic) law-making institution. On this approach, the traditional law-making process which requires the assent of the House of Commons, House of Lords and the Queen deserves no special sanctity, becoming as open to legislative reform as any other element of the constitution.

\footnotetext{
${ }^{71}$ Dicey, supra n. 3, p. 65-66.

${ }^{72}$ See W.I. Jennings, The Law and the Constitution, 5th edn (University of London Press 1959) p. 144-163; R.F.V. Heuston, Essays In Constitutional Law, 2nd edn (Stevens and Sons 1964) ch. 1.
} 
This 'manner and form' approach to parliamentary sovereignty has received renewed support as modern developments have prompted us to reconsider the blunt Diceyan approach to legislative power. Indeed, given the explanatory force of the 'manner and form' theory in relation to a range of modern legislative developments, including the incorporation of EU law into the UK's legal system, it should arguably now be seen as the new orthodoxy of parliamentary sovereignty. ${ }^{73}$ Against the general backdrop of this changing understanding of parliamentary sovereignty, the legal status of statutory referendum requirements raises special challenges. For even some who support a conception of parliamentary sovereignty which permits the legislature to establishing modest changes to the 'procedure and form' for law-making continue to have doubts about whether binding referendum requirements may be established.

Goldsworthy, for example, has defended the idea that Parliament can make some binding alterations to the future legislative process, yet argues that referendum requirements fall beyond the scope of what is permissible. For Goldsworthy, changes to the legislative 'procedure and form' can be enacted by a sovereign Parliament as long as they 'do not diminish Parliament's continuing substantive power to legislate'. ${ }^{74}$ Binding referendums requirements establish a 'veto' over decisions otherwise made by Parliament, ${ }^{75}$ which Goldsworthy suggests is an unacceptable constraint on sovereignty: 'by forbidding Parliament to enact law without the approval of an external body - namely, the electorate - it plainly limits its substantive authority. ${ }^{76}$

I have argued that this account takes an unnecessarily narrow view of the scope of Parliament's power to enact manner and form requirements for two main reasons. First, because parliamentary sovereignty does not require us to preserve Parliament's 'substantive power to legislate'. This doctrine concerns the existence of legislative power which is legally unlimited, but it does not require that this power can be easily exercised. Legislative sovereignty may be constrained in many ways, by moral, political, and practical factors, among others. Parliamentary sovereignty is about potential capacity rather than actual capability: what is possible, rather than what can actually be achieved. A referendum requirement may make it harder for Parliament to legislate, but as long as it does not make it impossible, it is compatible with this doctrine. ${ }^{77}$ Second, it seems wrong to regard the electorate

\footnotetext{
${ }^{73}$ See M. Gordon, Parliamentary Sovereignty in the UK Constitution: Process, Politics and Democracy (Hart Publishing 2015); M. Loughlin and S. Tierney, 'The Shibboleth of Sovereignty', 81 MLR (2018) p. 989 at p. 1008-1009.

${ }^{74}$ J. Goldsworthy, Parliamentary Sovereignty: Contemporary Debates (Cambridge University Press 2010) p. 194.

${ }^{75}$ Ibid., 199.

${ }^{76}$ Ibid., 138.

${ }^{77}$ Gordon, supra n. 73 , p. $102-104$.
} 
as an external body in possession of a veto over legislation. The authority of Parliament, and its claim to sovereignty, are based on the democratic character of the House of Commons. While the relationship between the people and their elected representatives is complex, the preferences of the electorate must already be a central consideration in a democratic legislative process. A referendum requirement can therefore be understood to represent the legislature requesting a specific affirmation of its general mandate to legislate in relation to a particular topic. In other words, a referendum requirement is a very special kind of manner and form condition - in giving a direct role to the electorate, it formalises what is already indirectly and politically relevant to the legislative process, rather than inserting a new alien perspective into the process of enacting statute law. ${ }^{78}$

Goldsworthy does accept that a change in 'the rule of recognition' underlying the UK constitution could alter our current understanding of parliamentary sovereignty, to the point where binding referendum requirements may be imposed. ${ }^{79}$ Yet it difficult to know how we could judge whether this had occurred - it might require near impossible questions to be answered by the courts (on the basis of very little legal evidence), ${ }^{80}$ and create considerable uncertainty about the status of any relevant statutory referendum requirement. ${ }^{81}$ The prospect of such an open assessment being decisive in establishing the binding (or otherwise) status of a statutory referendum requirement also inevitably raises challenging normative questions. Young has argued that to require a shift in the underlying constitutional consensus concerning the status of referendums may 'minimise some of the damaging effects of populism', ${ }^{82}$ by ensuring that the authority of representative institutions is not automatically subjugated to direct democratic decisionmaking. There is certainly a good democratic argument against the entrenchment of referendum requirements, which removes any future room for manoeuvre for the legislature by making the repeal of such a requirement itself conditional on a referendum first being held. Yet this need for caution should ultimately be a matter of political judgement, rather than rejected as a legal impossibility. ${ }^{83}$ Where the sovereign Parliament voluntarily opts to make its legislative power exercisable according to new procedures, and captures that decision in statute, it is difficult to see why this choice should be dismissed or diluted by other constitutional actors.

${ }^{78}$ Ibid., p. $271-273$.

${ }^{79}$ Goldsworthy, supra n. 74, p. 115.

${ }^{80}$ See H.L.A. Hart, The Concept of Law, 2nd edn (Oxford University Press 1994) p. 152-154: 'The truth may be that, when courts settle previously unenvisaged questions concerning the most fundamental constitutional rules, they get their authority to decide them accepted after questions have arisen and the decision has been given. Here all that succeeds is success'.

${ }^{81}$ Gordon, supra n. 73 , p. 218-222.

${ }^{82}$ See Young, supra n. 55, p. 196.

${ }^{83}$ Gordon, supra n. 73 , p. 308-309. 
This debate is not simply academic, for Parliament has in two contexts now enacted 'binding' referendum requirements of exactly the sort in question. First, in the context of the UK's relationship with the EU, Parliament enacted the European Union Act 2011, a wide ranging statute which sought to make certain decisions to pass new powers or competences to the EU conditional on approval in primary legislation and at a national referendum. ${ }^{84}$ This major constitutional experiment was never ultimately tested, as none of the EU Act's referendum requirements were ever triggered before the legislation was repealed upon the UK's exit from the EU. ${ }^{85}$ Nevertheless, prior to this, Parliament did establish a consistent pattern of legislative behaviour based on explicit compliance with the non-referendum procedural conditions established by the 2011 Act, ${ }^{86}$ and when called on to consider the extent of the referendum requirements, the courts did not dismiss these rules as beyond the scope of the legislature's power. ${ }^{87}$

Second, we have seen growing use of statutory referendum requirements in the context of devolution. The Northern Ireland Act 1998 has included a statutory referendum condition since the modern devolution arrangements were established, mirroring a provision contained in older legislation concerning the governance of Northern Ireland. ${ }^{88}$ By section 1(1) of the 1998 Act, a change to the status of Northern Ireland cannot occur without being approved at a referendum of the people of Northern Ireland. This legislative constraint is accompanied by a statutory obligation in section 1 (2), which requires the UK government to give effect to a referendum decision for Northern Ireland to leave the UK and join a unified Ireland. Related provisions have more recently been incorporated into Scottish and Welsh devolution law. These provisions do not establish a standing process according to which Scotland or Wales might exit the UK, but instead declare the permanence of the relevant devolved legislatures and governments, which 'are not to be abolished except on the basis of a decision of the people of Scotland [or, as applicable, Wales] voting in a referendum'. ${ }^{89}$ These provisions are perhaps moderated by some of the associated statutory language, which indicates that their purpose is 'to signify the commitment of the Parliament and Government of the United Kingdom' to the relevant devolved institutions. Yet while this may

\footnotetext{
${ }^{84}$ See especially European Union Act 2011, ss. 2, 3 and 6.

${ }^{85} \mathrm{EU}$ (Withdrawal) Act 2018, s. 23 and Sch. 9.

${ }^{86}$ See eg European Union (Approval of Treaty Amendment Decision) Act 2012; European Union (Approvals) Act 2013. For discussion, see Gordon, supra n. 73, p. 257-259.

${ }^{87} R$ (Wheeler) v The Office of the Prime Minister [2014] EWHC 3815 (Admin).

${ }^{88}$ See Northern Ireland Constitution Act 1973, s. 1. The Ireland Act 1949, s. 1(2) contained a similar provision, but in contrast to the 1998 and 1973 Acts, the procedural requirement included here was for the consent of the Parliament of Northern Ireland, rather than a referendum.

${ }^{89}$ Scotland Act 1998, s. 63A (inserted by the Scotland Act 2016, s. 1); Government of Wales Act 2006, s. A1 (inserted by the Wales Act 2017, s. 1).
} 
indeed be the purpose of these permanence clauses, their effect appears to be to establish a legal requirement that the UK Parliament could not legislate to abolish the Scottish Parliament, Welsh Senedd, or either devolved government, without it having been approved at a referendum in the relevant nation.

All of these 'binding' referendum requirements remain as yet untested. They are not entrenched, and the repeal of the EU Act 2011 indicates that what a sovereign Parliament can create can also be removed. But this does not mean that the EU 'referendum locks' were not binding while they remained in force. The clauses concerning the abolition of the devolved institutions may seem equally unlikely to be activated. Yet this is also part of the justification for understanding parliamentary sovereignty in such a way as to permit the creation of binding procedural limits - if it means statute law can better reflect the constitutional reality that it would be unimaginable for the UK Parliament to try unilaterally to remove the institutional foundations of devolved power in Scotland and Wales without popular approval in those nations, then this demonstrates the advantages of taking a flexible and functional approach to the scope of legislative power. Recent debates about whether a similar statutory provision might be used to embed UK commitments to the rights of EU citizens after Brexit show that our constitutional practice is moving beyond the idea that referendums must sit outside our mandatory law-making processes. ${ }^{90}$ In the aftermath of Brexit, the referendum requirement in the Northern Ireland Act may well be engaged if a reunification referendum is to be held - there can be no doubt that this legal commitment has a definitive role in shaping the process which would need to be followed for Northern Ireland to exit the UK.

This period of experimentation with binding statutory referendum requirements gives a clear prompt that parliamentary sovereignty should now be understood to accommodate such procedural change to the legislative process. The integration of referendums into the law-making process is contributing to important shifts in UK constitutional law. There remain questions about this trend: we have seen relatively creative experimentation with referendum requirements, but this has arguably been driven by a desire to send various political signals. The referendum conditions created could either be viewed as unnecessary - because they concerned decisions not realistically being contemplated, such as the transfer of further powers to the EU in 2011, or the abolition of the Scottish and Welsh devolved institutions in 2016 - or statutory placeholders to reconcile multiple

\footnotetext{
${ }^{90}$ No such provision was ultimately included in the EU (Withdrawal Agreement) Act 2020, despite prior suggestions in the Joint Report of the UK and EU Negotiators in December 2018; see M. Gordon, 'The European Union (Withdrawal Agreement) Bill: Parliamentary Sovereignty, Continuity and Novelty', UKCLA Blog (22 October 2019), 〈https://ukconstitutionallaw.org/2019/ 10/22/mike-gordon-the-european-union-withdrawal-agreement-bill-parliamentary-sovereigntycontinuity-and-novelty/ $/$, visited 14 July 2020 .
} 
competing positions at once, as in the reflection of both unionist and republican preferences in the process set out in the Northern Ireland Act 1998. Is this uncertainty inevitable, and evidence of the resilience of traditional understandings of parliamentary sovereignty, whereby the legislature 'cannot bind its successors' can 'binding' referendums exist in statute only if they cover circumstances which never materialise, so that in practice no-one is ever really 'bound'? Or is this simply evidence that the UK's experimentation with statutory referendum requirements is still nascent, and more systematic and testing use of such provisions is still to come?

What does seem clear is that use of referendums in the UK has moved beyond basic ad hoc deployment in circumstances defined contemporaneously by the government of the day. Referendums can no longer necessarily be seen as simple, singular, or limited legal mechanisms. There is a real diversity in their use, and a complexity to their status in law, regardless of whether they fall into the technical category of 'advisory' or 'binding' - indeed, the differences between them show that their formal legal status is just one part of their authority. Theoretically, both types of referendum are ultimately vulnerable to parliamentary sovereignty, yet in different ways both are resistant to parliamentary sovereignty as well. This may be more a matter of degree rather than kind, with the legal force of the outcome of a referendum just one part of a more complex constitutional mix of legal, political and moral considerations. As a result, we must look beyond the legal status of referendums in the UK, and consider their broader constitutional impact, which is similarly complex.

\section{THE CONSTITUTIONAL IMPACT OF REFERENDUMS}

The constitutional position of referendums cannot simply be assessed by examining the consistency with which they are used, or the formal legal status of the decisions reached. These factors are important, but there is also a deeper sense in which referendums might be seen to challenge the underlying norms and values of the constitution. The practice of making (some) decisions by referendum can potentially have a broader impact on the dynamics of the constitution. This constitutional impact extends beyond even the most significant technicalities governing the circumstances of their use, and generates questions about the nature and location of power in the political system. In particular, the use of referendums in the UK constitution requires us to reconsider the character of authority, the location of sovereignty, and the form of democracy within our political system. This raises questions at decreasing levels of abstraction, if we understand authority as concerning the nature of power, sovereignty as concerning the location of the final say, and democracy as concerning the decision-making process. 


\section{Authority}

In the manner they are incorporated into the UK's constitutional framework, referendums can have a potentially explosive effect on the character of authority within the state. In contrast to the regular authority of the legislative, executive and judicial organs established according to a standard constitutional distribution of powers, referendums have an irregular authority. When a decision is made by the electorate at a referendum, that decision is taken outside the established constituted powers. This happens sporadically rather than with any particular consistency, which compounds the irregular nature of what is occurring: the traditional constitutional organs are (at least in terms of the actual substantive decision to be taken) no longer the place where the authority to resolve a matter resides, albeit only for a particular matter at a particular (but difficult to anticipate) moment in time. The irregular authority of referendums means they are therefore potentially disruptive of both the political establishment and political expectations. This disruptive effect is not, of course, inevitable in practice. But it exists in principle, and - as in the 2016 Brexit referendum - becomes evident when the decision taken is to reject that status quo or the preferences of the political actors who must implement the decision.

The tension here between regular and irregular authority has a number of dimensions. First, when a referendum produces a result which usurps the expectations of established political actors, it still falls to them to implement the decision in exercise of their regular constitutional authority. Even if a referendum decision has pre-defined legal effects (not normally the case in the UK), the government and legislature will still need to take action in response to whatever changes in law or practice are instigated. ${ }^{91}$ For complex, multifaceted, open-ended questions like how to leave the EU, this leaves the regular political actors simultaneously constrained and in possession of huge discretion, which may be difficult to reconcile. Second, there is no standard timetable or 'electoral cycle' to respond to such a democratic expression of will. The consequences of a referendum decision may be easily and swiftly dealt with, or it may have effects which linger and define the priorities of the established constitutional actors for an unknowable period of time. In that sense, the exercise of the regular authority of the core political actors may be dominated by the irregular authority of the referendum decision for a length of time which is beyond their control. It may be left to the established constitutional authorities to define the process for delivering the referendum outcome, but that process may require revision and extension in ways which are

\footnotetext{
${ }^{91}$ For example, had a majority voted in favour of using the Alternative Vote in the 2011 referendum, much government activity would still have been necessary to prepare for the use of a new voting system for elections to the House of Commons.
} 
difficult to foresee at the outset. The creation of section 13 of the European Union (Withdrawal) Act 2018 to codify and legalise the role of the UK Parliament in the approval of any Withdrawal Agreement, by establishing the need for a 'meaningful vote', is a clear example of the way in which the legislature and executive had to reshape the process of responding to the 2016 referendum, with important but also ultimately inconclusive effects. ${ }^{92}$

The impact of the irregular authority of a referendum on the regular authority of the established constitutional actors is not inherently negative. No political system could ever function in a seamless fashion without unpredicted events or flawed delivery of planned goals: some irregularity must be expected. But that this irregularity emerges at the heart of the state's authority makes it particularly significant, given the regularity of the established constitutional institutions is an essential part of what generates their power. It is for this reason that referendums have the potential to disrupt the political establishment and their expectations to such major effect, something the UK is only just beginning to come to terms with following the 2016 decision to disconnect from the EU. Yet there are also positive aspects to this impact on constitutional authority - in principle a referendum provides a route for different inputs into what may be an overly closed political system, and alternative routes to accountability if political decisions are subject to direct popular confirmation. However, these schisms in authority can also be deployed as justification for subversion of the established political institutions: the unconstitutional attempt to prorogue Parliament to limit its ability to prevent a 'no deal' Brexit by 31 October 2019, provides a clear example of an attempt by the government to exploit the referendum's irregular authority to its own advantage in a dispute between the established institutions.

\section{Sovereignty}

A further constitutional impact of referendums is on our understanding of sovereignty. Sovereignty concerns the location of ultimate power within a constitutional framework. The UK constitution is organised explicitly around the fundamental idea of the sovereignty of Parliament, yet referendums seem to contradict this, establishing the sovereignty of the people. ${ }^{93}$ The combination of the atypical character of the UK's constitution and the increasing resort to decisionmaking at referendums therefore appears to generate a clash between two different conceptions of sovereignty: parliamentary sovereignty and popular sovereignty.

\footnotetext{
${ }^{92}$ See J. Simson Caird, 'The meaningful vote process has failed us', The Times (15 February 2019). The s. 13 requirement for a meaningful vote was ultimately displaced by the European Union (Withdrawal Agreement) Act 2020, s. 31.

${ }^{93}$ See V. Bogdanor, 'Europe and the Sovereignty of the People', Political Quarterly (2016) p. 1.
} 
This apparent inconsistency has been an influential source of hostility towards the use of referendums in the UK. Yet while Dicey, the leading defender of an orthodox understanding of parliamentary sovereignty, came to endorse the idea of referendums when it was politically expedient for him to do so, ${ }^{94}$ modern accounts which juxtapose parliamentary and popular sovereignty continue to exist, and have the potential to obscure rather than reveal. ${ }^{95}$

There is no doubt that referendums raise challenging questions about the location of ultimate power, and where the final say on any decision resides in our political system. These questions run deeper than debates about the formal legal status of a referendum outcome, and whether the result of such a process is binding or advisory. In principle, a legally unlimited sovereign Parliament can always overrule a decision reached at a referendum, or reverse any automatic legal consequences which have been prescribed to flow from its outcome. Yet this is to presume that the most important question in relation to sovereignty is how we resolve a competition between two entities for the formal final say. Instead, there is a need for more sophistication relating to different understandings of sovereignty, distinguishing between this as a legislative concept, as compared to a (relational) political principle. ${ }^{96}$

From this perspective, we can see that rather than an incompatibility between parliamentary and popular sovereignty, instead there is significant compatibility these two concepts, because they are primarily orientated to different contexts. Parliamentary sovereignty is an intra-constitutional principle: it determines the locus of law-making power within the UK constitution, and establishes an institutional hierarchy in which Parliament has primacy over all other official actors. Popular sovereignty, in contrast, is an extra-constitutional principle: it reflects the normative political value of democratic government. But the abstract normative idea that government must be democratically elected to have legitimacy will always need to be institutionalised in specific constitutional arrangements within a political system. Parliamentary sovereignty is one way to institutionalise the ideal of popular sovereignty, because it recognises that the UK's legislature has the strongest democratic credentials, in relative terms, when compared to the executive and the judiciary. But, equally, it is not the only way of doing so, nor indeed is it the most common way, given the overwhelming prevalence of codified constitutions in states around the world. A constitutional system in which the legislature

\footnotetext{
${ }^{94}$ See I. McLean and A. McMillan, 'Professor Dicey's Contradictions', $P L$ [2007] p. 435; in response, V. Bogdanor, 'The Consistency of Dicey: A Reply to McLean and McMillan', PL [2008] p. 19.

${ }^{95}$ For a recent example of this tendency, see R. Weill, 'The British Popular Sovereignty Model: A Play in Three Acts', DCU Brexit Institute Blog (26 January 2020), 〈http://dcubrexitinstitute.eu/ 2020/01/the-british-popular-sovereignty-model-a-play-in-three-acts/ $\rangle$, visited 14 July 2020.

${ }^{96}$ See M. Loughlin, The Idea of Public Law (Oxford University Press 2003) ch. 5.
} 
is limited by legal constraints enforced by the judiciary has no greater claim to be founded on popular sovereignty. ${ }^{97}$ Instead, these differences of constitutional form and institutional hierarchy simply show there are multiple models which give functional expression to the abstract notion of democratic government.

However, the conceptual compatibility of parliamentary and popular sovereignty, understood as principles operating on different planes, one intra-constitutionally and one extra-constitutionally, does not mean there is no space for tension. Technicalities can be masked in intense political debates, and the ideas of parliamentary and popular sovereignty may be pushed beyond their respective constitutional planes. Parliamentary sovereignty may become a normative ideal reflecting a preference for representative government, rather than simply an intra-constitutional doctrine concerning the location and nature of legislative authority. Popular sovereignty may be pulled into operation as a norm to challenge decisions made in the established constitutional institutions, despite its abstraction and lack of specificity about how a political system ought to be organised. We have seen expansive conceptions of both principles in constitutional debates about the implementation of the Brexit referendum, whether that is parliamentary sovereignty being stretched to signify the general (rather than legislative) supremacy of the legislature, ${ }^{98}$ or popular sovereignty being exploited to attack the hung Parliament of 2017-19 for blocking the will of the people. ${ }^{99}$ It is also possible for the popular sovereignty of groups within the state to be contrasted against the sovereignty of the central Parliament. ${ }^{100}$ But the popular sovereignty of a national or sub-national group within the state would still eventually need to be institutionalised in specific constitutional arrangements, whether parliamentary or otherwise. As a result, this is better understood as a claim for the sovereignty of the people within one state to be divided in two, which is not something that a legal doctrine of legislative sovereignty can (or should) be understood to prevent.

Whether instrumentalist or otherwise, contrasting parliamentary and popular sovereignty in such ways hinders a clear understanding of the categorical

\footnotetext{
${ }^{97}$ See B.C. Jones, Constitutional Idolatry and Democracy (Edward Elgar 2020). For the contrary argument, see A. Greene, 'Parliamentary Sovereignty and the Locus of Constituent Power' (forthcoming, International Journal of Constitutional Law).

${ }^{98} \mathrm{See}$ eg the critical discussion in the Divisional Court in the prorogation case of an 'expansive' approach to parliamentary sovereignty: $R$ (Miller) v The Prime Minister [2019] EWHC 2381 (QB) [58]-[64].

${ }^{99}$ See e.g. the Attorney General Geoffrey Cox, Hansard HC Deb, vol. 664, col. 660, 25 September 2019: 'Twice they have been asked to let the electorate decide whether they should continue to sit in their seats, while they block 17.4 million people's votes. This Parliament is a disgrace'.

${ }^{100}$ See eg Scottish Government, Scotland's Right to Choose: Putting Scotland's Future in Scotland's Hands (2019) p. 5.
} 
distinction between these ideas. There is little use in complaining, however, about conceptual imprecision in heated political debates, and whether relating to the Brexit process or a Scottish independence referendum, these existential questions have a special capacity to give particular prominence to matters of sovereignty. Yet parliamentary and popular sovereignty do not represent irreconcilable power claims, and to see them as such can generate uncertainty about how political institutions should respond to referendum decisions, potentially exacerbating both stasis and division. In contrast, when we recognise the complementary character of these different principles, we can see the variability which is possible in constitutional design. There is a complex relationship between the people and their elected representatives, with no need to choose definitively between them. Instead, a more sophisticated understanding of the alternative realms in which different sovereignty claims operate allows us to think about the situations in which more or less direct popular decision-making will be justified. In this sense, we can avoid a preoccupation with false dichotomies of sovereignty, and focus on determining which kinds of decisions ought to be taken following the collective input of the electorate.

\section{Democracy}

Finally, referendums also have a significant impact on the form of democracy which defines our constitutional systems. They constitute a departure from the representative model of democracy which remains dominant across democratic political systems, in providing a means for the people to take a decision directly, rather than indirectly through their chosen representatives. The existence of different democratic processes for decision-making raises crucial questions about the identity of the optimal decision-maker - who should decide what, and when? As we have seen, it is constitutionally permissible for the legislature to pass decisions on to be taken directly by a majority of the electorate, for this is simply one among a number of ways of institutionalising the idea of popular sovereignty. But in what circumstances should this be done? This is not a standard or technical decision about what decision-maker is best equipped to make a choice. Instead, it goes to the core of our understanding of democracy, and the meaning of government by and for the people. For some, the people should choose their representatives and trust their skill and judgement in taking key political decisions. ${ }^{101}$ For others, this is to circumvent the actual opinions of the people, and more direct, specific instructions are required on an ongoing basis to ensure the actions of the governing elites reflect the views of the wider population. ${ }^{102}$

\footnotetext{
${ }^{101}$ See famously E. Burke, Speech to the Electors of Bristol (3 November 1774).

${ }^{102}$ See Bogdanor, supra n. 2, p. 91-93.
} 
This normative clash between representative and direct democracy is in practice irresolvable. There is no absolute way of deciding which conception of democracy is superior, or in what circumstances, or for what categories of decision, these differing democratic processes should be used. The scale and complexity of the modern state is such that the overwhelming majority of decisions are taken on a representative basis, whether by the Parliament which is (at least in the Commons) directly elected, or by the government which derives its democratic mandate indirectly from the composition of the legislature. In the face of this reality, and in the absence of any definitive criteria establishing the ideal parameters of representative and direct democracy, the challenge is to move beyond simplistic claims of the superiority of either model. Instead, the constitutional dilemma is how to exploit the potential offered by the effective combination of these different democratic processes. We should avoid the reductivism of presenting this as a clash between two competing ideals, and rather focus on ways of structuring their interaction which generate complementarity. This is especially the case given the complexity of the relationship between representative and direct democratic processes: in the UK the representative institutions in general have the power to determine when a matter should be put to a direct democratic decision and how to implement it, yet at the same time the authority of a specific choice made by the electorate will be immense.

Against this backdrop, the key question is how the constitution should determine when decisions should be made directly by the people, usually in the form of the referendum. As we have seen, in the UK referendums have largely been reserved for decisions which would prompt significant constitutional change. But how do we decide when decisions are of the requisite degree of constitutional sensitivity? And should referendums only be for questions of 'major constitutional significance' to begin with? If this is simply about different processes for decisionmaking, a test of constitutional significance may not be appropriate to trigger potential recourse to direct democracy. There is nothing inherent in these different democratic processes which suggests that direct democracy should be preserved only for an exclusive category of 'higher order' decisions, however they might be defined. Indeed, rather than focusing exclusively on major, complex, constitutional questions in referendums (at least at the national level), logic might suggest that simple, more mundane decisions might also be suitable for direct democratic resolution. This is not simply to expand the possible scale of direct democracy in the UK's political system, but also to reconsider the type of decisions which might be appropriate for the electorate to determine directly.

If this path is followed it might challenge us to rethink the idea of democracy as it operates in our political system. There could, of course, be many objections to such a change in approach. Regular referendums might be difficult to deliver or institutionalise. They might be claimed to lead to electoral disinterest or voter 
fatigue. If offering a decision to the electorate inevitably requires it to be simplified to a point where complexity is subsequently unavoidable at the implementation stage, direct democracy may seem to be a mirage. If the representative institutions have the initiative as to when a referendum should be held, it may become an elite tool for policy confirmation. And if those decisions can then be appropriated by representative institutions to claim a reinforced mandate, such as Prime Minister Boris Johnson's 'people's government', ${ }^{103}$ the extent to which direct democracy really represents some break with the dominant paradigm of representation may be open to doubt. ${ }^{104}$

The alternative view, however, is that broadening our conception of different forms of democratic power allows flexibility in the design of decision-making processes. Direct democracy in general, and referendums in particular, can be organised in different ways for different purposes - as is clear from the diversity of national experiences, they may be confirmatory, consultative, agenda setting, and more. ${ }^{105}$ And this can provide different avenues in the constitution for different groups or constituencies to shape policy making, or indeed to take authoritative decisions, on constitutional matters and beyond. As a result, the use of referendums in the UK constitution does not generate an irresolvable clash between direct and representative democracy, but it does prompt us to reconsider the suitability of different democratic processes for various categories of decision. There are no easy answers (whether before or after the Brexit referendum) but to recognise the variability within the idea of democracy is surely better than either indulging in complacency about our representative democratic model, or assuming direct democracy should only be a last resort when faced with exceptional questions.

\section{WHAT NEXT?}

Having considered the use, status and conceptual impact of referendums on the UK constitution, we can see that their cumulative effect has been far-reaching and pervasive. The use of referendums has lacked consistency or serious justification. There are some extant legal questions about the status of referendums, but this

\footnotetext{
${ }^{103 ‘}$ Election results 2019: Boris Johnson's victory speech in full' BBC News (13 December 2019), 〈www.bbc.co.uk/news/election-2019-50777071〉, visited 14 July 2020.

${ }^{104} \mathrm{On}$ the limitations of referendums, see M. Qvortrup, 'Introduction: Theory, Practice and History', in M. Qvortrup (ed.), Referendums Around the World (Palgrave 2018). See also M. Setala, Referendums and Democratic Government: Normative Theory and the Analysis of Institutions (Palgrave 1999); L. deLuc, The Politics of Direct Democracy: Referendums in Global Perspective (University of Toronto Press 2003).

${ }^{105}$ Venice Commission, supra n. 6.
} 
also presents a potential distraction if it is taken as the key issue concerning the constitutional position of these democratic tools. The deeper impact of referendums has been in challenging some of the core concepts of the UK constitution: the regularity of established institutional authority, the sovereignty of the UK Parliament, and the representative form of our democratic model. Yet the challenges posed are not straightforward - irregular authority may unsettle the established order in ways that are positive as well as negative. Parliamentary sovereignty is not displaced by popular sovereignty when this is simply one way of institutionalising that extra-constitutional democratic ideal, and direct and representative democracy may be approached as complementary rather than competitors, raising key questions as to the weight to be attributed to each.

What comes next, then, for referendums in the UK? While the Brexit referendum has had a seismic impact on the UK constitution, it is not a juncture from which one direction or another must inevitably be forged. Nevertheless, the prominence of this referendum in the UK's public life means it presents an important opportunity to take stock of what might lie ahead. The multidimensional impact on core constitutional ideas suggests that the role of referendums in the constitution cannot be considered as a single matter in isolation, but must instead be examined in connection with a wider range of issues concerning the changing character of democratic practice. ${ }^{106}$ Yet is the growing significance of the referendum simply part of a normal pattern of democratic and political change as society evolves? ${ }^{107} \mathrm{Or}$ is this suggestive of a realignment occurring in the normative foundations of the UK's political system?

We should not overreact to the challenges posed by 'new' mechanisms for democratic decision-making, nor try to stem the development of political ideas by attempting to freeze the state at a specific arbitrary moment when representative democracy is ascendant. The referendum has not forced us to abandon old ideas of authority, sovereignty or democracy in the UK constitution. But the considerable constitutional impact of the referendum does prompt us to ask new questions about how we understand these key concepts, both to clarify how the position of our established institutions and norms has been complicated, and to think about how we might alter our future practice to respond to these significant shifts. It is unhelpful to present a solution as based on the choice between stark alternatives, for there is a risk that this would compound, rather than attenuate, the existing tensions. Instead, we need to recognise the existence of a framework in

${ }^{106}$ See E. Daly, 'A Republican Defence of the Constitutional Referendum', 35 Legal Studies (2015) p. 30; A.L. Young, 'Populism and the UK Constitution', 71 Current Legal Problems (2018) p. 17 at p. 26-28, 37-38.

${ }^{107}$ See D. Butler and A. Ranney (eds), Referendums Around the World: The Growing Use of Direct Democracy (Macmillan 1994); M. Qvortrup, Government by Referendum (Manchester University Press 2018). 
which constitutional choices can be recalibrated. This means we are not forced to choose between regular and irregular authority, parliamentary and popular sovereignty, or representative and direct democracy, but should see these concepts as framing a range of available options for the organisation of constitutional decision-making. In turn, accepting the need for decisions both about and within a wider framework in the UK shows that the challenge here extends beyond individual referendums (or their legal status or effects), and requires more than the passive observation of constitutional evolution. In such circumstances, we should face the practical challenge of addressing the position of referendums in the constitution more clearly.

\section{Ignored, embraced, accommodated: a UK Referendums Act?}

How might the position of the referendum in the UK constitution change in the future? There are a number of possibilities. In broad terms, we might see three potential options: the referendum might be ignored, embraced or accommodated.

First, for some Brexit may be a temptation to call for no more referendums in the UK. ${ }^{108}$ Yet even if we set aside the normative debate about whether referendums are an important way of passing key decisions to the people directly, or a crude tool which politicians can manipulate for their own ends (or both), the referendum now seems too well established in our constitutional life to be ignored. While long running debates about a second referendum on Brexit are now over, the consequences of Brexit have already reignited debate about a second Scottish independence referendum, ${ }^{109}$ and even a referendum on the reunification of Ireland. ${ }^{110}$ As we have seen, the referendum is incorporated into the Northern Ireland Act 1998 as an essential part of the process of changing the status of Northern Ireland, as well as featuring in other parts of our devolution legislation. It is equally impossible to imagine any future campaign for re-entry to the EU being able to avoid a commitment to a referendum on any such plan, given the way the decision to leave was taken. The moral appeal of passing a difficult decision directly to the electorate, alongside the potential political utility of the referendum as a means to legitimise major change, means this mechanism is likely to

${ }^{108}$ J. Curtice, 'Should Britain banish referendums?', The British Academy (16 February 2017), 〈www.thebritishacademy.ac.uk/blog/should-britain-banish-referendums〉, visited 14 July 2020; M. Kettle, 'If referendums are the answer, we're asking the wrong question', The Guardian (23 June 2016), 〈www.theguardian.com/commentisfree/2016/jun/23/referendums-answer-wrongquestion-politics-destruction $\rangle$, visited 14 July 2020.

${ }^{109}$ P. Sim, 'Scottish independence: could a new referendum still be held?', BBC News (31 January 2020), (www.bbc.co.uk/news/uk-scotland-scotland-politics-50813510〉, visited 14 July 2020.

${ }^{110} \mathrm{~J}$. Stone, 'Ireland election: Referendum on border "inevitable", says ex-premier after Sinn Fein surge', The Independent (11 February 2020), (www.independent.co.uk/independentpremium/world/ ireland-election-result-border-referendum-sinn-fein-bertie-ahern-a9328196.html $\rangle$, visited 14 July 2020. 
continue to feature in the toolbox of those in power. The referendum may also provide a useful vehicle for those who wish to slow down or create obstacles to reform - it is easy to imagine opponents of House of Lords or electoral reform insisting that a government elected with a manifesto commitment to change these aspects of the constitution would still require the specific, additional approval of the people to implement those policies. In that sense, even if we try to ignore referendums, an implicit and inchoate framework concerning their use will continue to function regardless.

The second option is to think about how to embrace the advantages of referendums while avoiding the pitfalls. While this presents challenges, there are also virtues which can be discerned from the constitutional impact of referendums which we should not too readily dismiss. In relation to authority, we see referendums have the potential to subvert the expectations and priorities of the established institutions. In relation to sovereignty, we see the varied realities of modern power, and the need to ensure popular perspectives are addressed before reaching the point where sections of the population are alienated from, and use their votes to confront and override, the political consensus. In relation to democracy, the Brexit process and the political response to the referendum have shown that the limits of representative democracy are just as significant as the limits of direct democracy.

The problem with the UK's current approach to referendums may be that we focus all energy and attention on one politically canonical decision, with little serious preparation for that moment, and no follow up opportunities for the people to directly influence the way their choice is being implemented. An all-or-nothing approach of this kind is arguably reinforced by flawed narratives which suggest the referendum is a foreign or atypical constitutional device, and inevitably raises expectations to a level which any decision-making process would struggle to meet. If the referendum is now an established element of UK practice, we might try to defuse this pressure in a constitutional framework which offers greater (although inevitably not complete) regularisation of its place in our political system.

How might this be done? We might consider formalisation of the appropriate relationship between direct and representative democratic inputs, by attempting to determine more precisely the circumstances in which referendums should be held. Despite the scepticism about this encountered earlier in the paper from both the House of Lords Constitution Committee and the Independent Commission on Referendums, it may be time to at least map out how more certainty could be achieved. The most obvious way this could be done would be through a new Referendums Act. This could include establishing a definitive list of major constitutional events which required approval at a referendum. But it would not need to be limited to this. A Referendums Act could be drafted to establish binding referendum requirements, but also a process of legislative initiative through referendums. It could present an exhaustive list of circumstances in which referendums were necessary, or supplement this with a set of evaluative criteria to be used 
to determine the suitability of a referendum in novel situations. It could empower a new institution (perhaps a Referendums Commission) to issue guidance about whether those criteria had been met. Regularisation in statute need not mean inflexibility or a narrow focus on creating popular vetoes for constitutional change. A Referendums Act would not need to be entrenched, and could still be altered (and therefore perhaps circumvented) by future Parliaments - yet the very act of creating such legislation, if underpinned by adequate political consensus, would mean that it could establish a clearer framework with the authority to shape decisions concerning when a referendum should be held (or not), for what purpose, and with what effects. This would not necessarily mean an expansion of referendums to new circumstances - the breadth of situations covered by such an Act would be a matter of great importance, and subject to much disagreement. Yet such statutory reform might provide greater coherence to our current practice, and at the very least would provide an opportunity to consider the big questions of principle as much as the technical questions regarding our use of referendums. ${ }^{111}$ While the former questions are the most difficult, they are also the ones which we have failed to explore in any systematic way. ${ }^{12}$

In addition to questions about whether these ambitions could ever attract sufficient political support to be delivered in practice, there are two deeper objections. First, would the creation of a Referendums Act make the decision to call (or not to call) a referendum justiciable in the courts? Primarily this would be a matter of legislative design. The practice of strictly constraining the timetable and grounds on which a referendum result can be challenged in the enabling legislation is well established. ${ }^{13}$ The possibility therefore clearly exists for Parliament to enact provisions restricting litigation challenging a decision to hold a referendum under the terms of such an Act, or even to impose an ouster clause to prevent legal challenge to such decisions outright. ${ }^{114}$ The intensely political nature of a decision to hold a referendum would provide a clear justification for restriction of judicial review in this context. Indeed, this is something which may be

${ }^{111}$ See further L. Trueblood, 'Legislating for referendums in the United Kingdom', Public Law [2020] p. 49-55.

${ }^{112}$ They have also not been addressed in recent legislation enacted by the Scottish Parliament, which, much like the Political Parties, Referendums and Elections Act 2000 at the UK level, is instead focused on establishing a regulatory framework within which referendums will be held; see Referendums (Scotland) Act 2020.

${ }^{113}$ The standard period in which a challenge can be brought is within six weeks from the confirmation of the result; eg European Union Referendum Act 2015, Sch. 3, para. 19.

${ }^{114}$ Although an ouster clause might be contested, as the courts could seek to re-interpret its meaning to limit its effects, or (more unlikely) take the legally dubious but occasionally threatened step of attempting to override such a clause outright; see Privacy International v Investigatory Powers Tribunal [2019] UKSC 22. 
welcomed by the judiciary, who have already shown some reluctance to become involved in assessing the legality of referendum processes unless explicitly required to do so. For example, as the Court of Appeal indicated in $R$ (Wilson) $v$ The Prime Minister, a challenge to the legality of the Brexit referendum:

'Parliament has set out the circumstances on which the court may interfere with the EU referendum result - there must a strong presumption that it did not intend the court to interfere otherwise. In any event, where, as here, the vote is only advisory, and Parliament has retained ultimate control over the question of whether the UK leaves the EU, I am entirely unpersuaded that the courts have any residual common law power to interfere. ${ }^{115}$

The extent of any judicial oversight of such decision-making would therefore be a choice for Parliament. And a Referendums Act which did not increase the role of the courts in this sphere would not be lacking in purpose - indeed, the formalisation of expectations and institutionalisation of a clearer political process concerning referendum decisions which such legislation might offer would arguably be undermined by the uncertainty judicialisation could generate.

The second constitutional objection to a Referendums Act concerns the potential impact on parliamentary sovereignty. Could Parliament bind its successors to embrace such a framework, or its application to specific circumstances? Would the systematic provision for referendums in specified situations constitute a final, decisive shift to a constitutional system based on popular sovereignty? Should such a Referendums Act be firmly entrenched to be meaningful? These questions raise important issues, but also arguably remain rooted in an understanding of parliamentary sovereignty which is now outdated. The vast flexibility of Parliament's legislative power is key. Parliamentary sovereignty establishes unlimited options for future reform, which allows us to think radically rather than see the traditional doctrine as a barrier to change. ${ }^{16}$ Parliament's changing legislative practice must guide our understanding of its sovereignty, instead of viewing sovereignty as a constraint on Parliament's legislative practice. From that perspective, the starting point must be that a Referendums Act is possible, it could have an impact on the decisionmaking process applicable to future Parliaments, but would be contributing to an existing pattern of legislative engagement with referendums, and not displacing legislative sovereignty. Much would depend on the details, but the openness of parliamentary sovereignty leaves considerable scope for the further integration of referendums into the UK constitution. Parliamentary sovereignty is therefore neither a

${ }^{115}$ [2019] EWCA Civ 304, [36].

${ }^{116}$ See M. Gordon, 'Parliamentary Sovereignty and Constitutional Futures', in A. Bogg et al. (eds.), The Constitution of Social Democracy: Essays in Honour of Keith Ewing (Hart Publishing 2020). 
normative nor a legal barrier to using legislation to redesign the constitutional framework in which UK referendums sit.

Perhaps enacting a Referendums Act or pursuing any other elaborate reform is unachievable. Political consensus about the role of referendums may not exist, and legislation may not be regarded as the right vehicle for such reform. If that is the case - whether right now or for the longer term - we encounter the third option for the future of the referendum: accommodation within the UK constitution. This may seem the most likely path, and means we will continue to approach referendums on an ad hoc basis. Some consistency in the circumstances of their usage may continue to develop over time, but our constitutional deployment of referendums would be generally unplanned and reactive. A second independence referendum in Scotland provides an obvious example of such constitutional accommodation of referendums. It is widely accepted that a referendum will be necessary to decide the question, and a lawful referendum process will be required to generate legitimacy for the ultimate result. ${ }^{117}$ It may also be argued that certain democratic events would definitively demonstrate a popular mandate for a second referendum to be held, such as the re-election in Scotland in 2021 of a Scottish National Party government on a manifesto promising such a vote. Yet there is no clarity about whether this sets the bar too high, as the current SNP government have suggested, in arguing that the UK's withdrawal from the EU contrary to the wishes of a majority of the Scottish electorate already provides a sufficient reason for another referendum. ${ }^{118}$ Or whether the UK government could simply continue to refuse to engage in negotiations concerning a second referendum at all, on the basis it was a 'once in a generation event'. ${ }^{119}$ This standoff is unlikely to lead to stasis, but instead reopen further challenging questions about whether the Scottish Parliament has the legislative competence to call an 'advisory' referendum in a different sense. For even if to call such a referendum was lawful, the result of that vote would be one which the Scottish legislature could not unilaterally enforce, at least within the parameters of our current constitutional system. ${ }^{120}$

${ }^{117}$ See A. McHarg and C. McCorkindale, 'Constitutional Pathways to a Second Scottish Independence Referendum' UKCLA Blog (13 January 2020), 〈https://ukconstitutionallaw.org/ 2020/01/13/chris-mccorkindale-and-aileen-mcharg-constitutional-pathways-to-a-second-scottishindependence-referendum/ $/$, visited 14 July 2020.

${ }^{118}$ Scotland's Right to Choose, supra n. 101, p. 11-18.

${ }^{119}$ 'Letter from PM Boris Johnson to First Minister Nicola Sturgeon' (14 January 2020), (www. gov.uk/government/publications/letter-from-pm-boris-johnson-to-scottish-first-minister-nicolasturgeon-14-january-2020 , visited 14 July 2020.

${ }^{120}$ Under the Scotland Act 1998, Sch. 5, Part 1, para. 1(b), 'the Union of the Kingdoms of Scotland and England' is a matter reserved to the UK Parliament. Even if an indicative referendum is held to be within the power of the Scottish Parliament, giving domestic legal effect to a vote in favour of independence would therefore require a UK Act of Parliament. 
The accommodation of referendums may seem rooted in political and constitutional incrementalism, avoiding major structural reform and even loose commitments, in favour of responding to challenges if and when they arise. There is value in such an approach, which can still be improved by better regulation of the way referendums are conducted, and connecting referendums with wider processes of democratic deliberation. ${ }^{121}$ However, considering the alternatives shows us that constitutional accommodation need not be the inevitable approach to referendums in the UK. The obstacle to a fuller embrace of referendums is not the incompatibility of this mechanism with our constitutional system, but an underlying uncertainty of constitutional vision. We need to know what we want from our democratic system to know how the constitutional framework can support this. The accommodation of referendums serves the useful purpose of keeping open the normative question of the constitutional desirability of referendums, whereas embrace (or indeed rejection) does not. It may do so pending some further reflection on the constitutional position of referendums, or it may be an end state in itself. Yet even if constitutional accommodation is dominant at present, and likely to remain that way, we must recognise that for greater coherence in the use of referendums in the UK, there will be a trade-off: formalisation and increased commitment in a Referendums Act must be based on a political choice to accept a reduction in manoeuvrability. This would align our approach to direct democracy more closely with the type of framework in which our typical representative democratic events occur, although even if referendums are constitutionally embraced, attitudes to them will still have some way to develop before they reflect the embedded political culture which underpins general (and national) elections.

\section{Conclusion}

Referendums have played a major role in prompting and shaping contemporary change to the UK constitution. They have been used in a range of different contexts, without being subject to any overarching legal (or indeed political) framework determining the circumstances in which they are to be used. This may be due to their traditionally anomalous position in the UK constitution, and the complex questions concerning the legal status of referendums due to the dominance of the doctrine of parliamentary sovereignty. Yet in practice this has not stopped experimentation with different kinds of referendum requirements, and their legal integration into statutory decision-making processes. And in theory, we can see alternative ways to understand parliamentary sovereignty which permit

\footnotetext{
${ }^{121}$ See especially Tierney, supra n. 4; J. Organ, 'The Legal Regulation of Campaign Deliberation: Lessons from Brexit', Politics and Governance (2019) p. 268.
} 
rather than prohibit more elaborate legislative deployment of these democratic mechanisms. Nevertheless, the constitutional impact of referendums has been significant, and continues to fluctuate.

Referendums pose unavoidable questions concerning the changing nature of authority, sovereignty, and democracy in the UK constitution, demonstrating that to aim to restore the 'old constitution' would be futile. Our social and political context has changed, and even if the constitution fails to exploit or channel the end of the 'age of deference', it cannot avoid changing to reflect it. The future position of referendums is therefore one part of a larger constitutional challenge, to which there are a range of possible answers. It is far from inevitable that any systematic reform to the position of referendums will ever occur, yet if a coherent scheme, consistency of use, and clarity of application are our democratic aspirations, then greater legal and political commitment to referendums could be within reach through a Referendums Act. However, the failure to establish a comprehensive framework may be less significant than the failure to even recognise this possibility, which demonstrates a rigidity and a refusal to see how the UK constitution is being changed in practice. We can continue to accommodate referendums, whether 'advisory' or 'binding', in the UK constitution. But whether through a Referendums Act or otherwise, there is now a need to examine the wider constitutional framework in which referendums exist, or this will continue to limit our capacity to respond to the changing expectations and complexities of democratic power. 